\title{
Transmission of an Arenavirus in White-Throated Woodrats (Neotoma albigula), Southeastern Colorado, 1995-1999
}

\author{
Charles H. Calisher,* Scott Nabity, $t$ J . J effery Root,* \\ Charles F. Fulhorst, $\neq$ and Barry J . Beaty* \\ *Colorado State University, Fort Collins, Colorado, USA; †University of Michigan, Ann Arbor, \\ Michigan, USA; and $\ddagger$ University of Texas Medical Branch, Galveston, Texas, USA
}

\begin{abstract}
From 1995 to 1999, we conducted longitudinal studies of white-throated woodrats (Neotoma albigula) in southeastern Colorado. Forty-five (42.9\%) of 105 female and $15(26.8 \%)$ of 56 male $N$. albigula had antibodies against Whitewater Arroyo virus (WWAV). Sixteen female and three male N. albigula seroconverted during the study period, most of them during July-November, when population densities are highest. Analyses of longevity data, minimum numbers alive and infected, movements, and weight data suggest that the dominant mode of WWAV transmission among white-throated woodrats in Colorado is direct contact. WWAV was recently reported to cause fatal infection in humans. Our findings will lead to better assessment of the public health threat posed by infected woodrats and may be useful in predicting periods of increased risk for human infection.
\end{abstract}

\begin{abstract}
Arenaviruses (order Mononegavirales, family Arenaviridae, genus Arenavirus) are grouped into two complexes on the basis of phylogenetic analyses of viral RNA and serology: the Old World or lymphocytic choriomeningitis-Lassa virus complex viruses and the New World or Tacaribe complex viruses (1). The principal hosts of the Old World and New World arenaviruses are murine (subfamily Murinae) and sigmodontine (subfamily Sigmodontinae) rodents, respectively, of the order Rodentia, family Muridae. Arenaviruses establish chronic infections in their specific rodent hosts.

In a recent study, antibody to arenaviruses was detected in Neotoma sp. rodents (2), suggesting that in the southern and western United States an unrecognized arenavirus was associated with woodrats, genus Neotoma. Fulhorst et al. (3) then isolated an arenavirus from a white-throated woodrat, Neotoma albigula, captured at Whitewater Arroyo, New Mexico. Whitewater Arroyo virus (WWAV) is antigenically and genetically most closely related to Tamiami virus, which was isolated from hispid cotton rats (Sigmodon hispidus) in Everglades National Park in south Florida and had been the only Tacaribe complex arenavirus known to occur in North America (4).

We conducted longitudinal mark-recapture studies of rodents at study sites in Colorado to determine the epizoology of hantaviruses at those sites. From January 1995 to November 1999, we collected blood samples from woodrats, including sequential samples from individual rats, at a shortgrass prairie habitat in a canyon in southeastern Colorado. These studies showed that WWAV is highly prevalent in
\end{abstract}

Address for correspondence: Charles H. Calisher, Arthropod-Borne and Infectious Diseases Laboratory, Department of Microbiology, Foothills Campus, Colorado State University, Fort Collins, Colorado 80523, USA; fax: 970-491-8323; e-mail: calisher@promedmail.org woodrats. We present data on the dynamics of WWAV infection and epizoologic and kinetic factors affecting the natural history of this virus.

\section{Materials and Methods}

\section{Study Sites}

Rodents were trapped at the U.S. Army Pinon Canyon Maneuver Site (PCMA) located in Las Animas County, southeastern Colorado. The site (area $>1,040 \mathrm{~km}^{2}$ ) is a shortgrass prairie habitat managed by the Directorate of Environmental Compliance and Management, Fort Carson, Colorado. We established two study sites, MRC (at the mouth of Red Rocks Canyon) and RRC (inside Red Rocks Canyon) (Appendix).

\section{Trapping and Processing}

For 3 nights approximately every 6 weeks from January 1995 to December 1999, we placed 145 traps in a web pattern at the MRC site and 75 traps in an irregular grid at the RRC site. A Sherman trap, $7.6 \mathrm{~cm} \times 8.9 \mathrm{~cm} \times 22.9 \mathrm{~cm}$, (H.B. Sherman Traps, Inc., Tallahassee, FL) was placed at each trap station, and the locations were marked. We conducted 14,790 trap-nights at the MRC site and 7,650 at the RRC site, using the mark-recapture-release methods recommended by the Centers for Disease Control and Prevention (5) as described for Colorado sites (6).

Weight classes were defined for white-throated woodrats as follows: for female rats, $50 \mathrm{~g}$ to $100 \mathrm{~g}=$ juvenile, $101 \mathrm{~g}$ to 150 $\mathrm{g}=$ subadult, and $151 \mathrm{~g}$ to $300 \mathrm{~g}=$ adult; and for male rats, 50 $\mathrm{g}$ to $100 \mathrm{~g}=$ juvenile, $101 \mathrm{~g}$ to $200 \mathrm{~g}=$ subadult, and $201 \mathrm{~g}$ to $300 \mathrm{~g}=$ adult (7).

Blood samples were stored on dry ice and transported to the Fort Collins laboratory, where they were stored at $-70^{\circ} \mathrm{C}$ 


\section{Research}

until they were tested for antibody (8). Data were analyzed by Epi-Info, version 5.0 (9).

\section{Antibody Assays}

All samples were tested for immunoglobulin ( $\mathrm{Ig}$ ) $\mathrm{G}$ antibody by indirect immunofluorescence assay (IFA) (10), using a mixture of anti-rat and anti-mouse antibodies conjugated to fluorescein isothiocyanate, and by enzymelinked immunosorbent assay (ELISA) (11), using WWAV antigens prepared from Vero E6 cell monolayers infected with WWAV prototype strain AV 9310135 (Table 1).

We calculated relative abundance (minimum number alive [MNA]), minimum number known to have antibody to WWAV (MNI), estimated standing prevalences of antibody to WWAV (ESP [MNI/MNA]), and incidence of infection (number of new infections/100 rats/month) for $N$. albigula. If a sample had discordant results by the two methods, we did not consider it positive. Seroconversions were defined as fourfold or greater increases or decreases in IgG antibody titer as determined by ELISA.

\section{Results}

The first woodrats were captured in May 1995 at each site. Of 306 samples tested, 207 (67.6\%) were negative in both assays, and $37(12.1 \%)$ were positive at $4+$ for IFA and $>51,200$ for ELISA (Table 1). Antibody, as determined by both IFA and ELISA, was detected in all three woodrat species (N. albigula; N. mexicana, Mexican woodrat; and N. micropus, southern plains woodrat) captured at PCMS (Table 2). Fortyfive $(41.7 \%)$ of 108 female and $15(26.8 \%)$ of 56 male $N$. albigula (60 [36.6\%] of 164 seropositive rats) captured at least once had antibody to WWAV. Of these 164 rodents, 108 $(65.9 \%)$ were female, representing $45 \quad(75 \%)$ of all seropositives. These proportions did not differ significantly (Yates corrected chi square $1.19, \mathrm{p}=0.28$ ). Two of 25 Mexican woodrats and 2 of 11 southern plains woodrats had antibody to WWAV (Table 3). Seroconversion was detected in 16 $N$. albigula (13 female and 3 male; Figure 1); most seroconversions (in 9 female and 3 male rats) occurred from July to November.

The range of MNA for $N$. albigula during this study was 0 to 23 (August 1995), with 11, 17, and 10 later in that year
Table 2. Antibody to Whitewater Arroyo virus in woodrats (Neotoma spp.) by sex, Piñon Canyon Maneuver Site, Colorado, 1995-1999

\begin{tabular}{llcccc}
\hline & & \multicolumn{2}{c}{ Single samples } & \multicolumn{2}{c}{ Multiple samples } \\
Neotoma & spp. & Female & Male & Female & Male \\
\hline albigula & Pos. & $21(33.3 \%)$ & $10(22.7 \%)$ & $24(53.3 \%)$ & $5(41.7 \%)$ \\
& Neg. & $42(66.7 \%)$ & $34(77.3 \%)$ & $21(46.7 \%)$ & $7(58.3 \%)$ \\
mexicana & Pos. & $0(0)$ & $2(20 \%)$ & 0 & 0 \\
& Neg. & $9(100 \%)$ & $8(80 \%)$ & 4 & 2 \\
micropus & Pos. & $1(16.7 \%)$ & 1 & 0 & 0 \\
& Neg. & $5(83.3 \%)$ & 1 & 2 & 1 \\
\hline
\end{tabular}

Table 3. Prevalence a of antibody to Whitewater Arroyo virus in rats collected in southeastern Colorado, 1995-1999

\begin{tabular}{lcccc}
\hline Site & $\begin{array}{c}\text { Neotoma } \\
\text { albigula }\end{array}$ & $\begin{array}{c}N . \\
\text { mexicana }\end{array}$ & $\begin{array}{c}N . \\
\text { micropus }\end{array}$ & $\begin{array}{c}\text { Sigmodon } \\
\text { hispidus }\end{array}$ \\
\hline Mouth of Red & $26 / 64$ & 0 & $1 / 2$ & $0 / 86$ \\
Rocks Canyon & $(40.6 \%)$ & & $(50 \%)$ & $(0)$ \\
Inside Red & $12 / 36$ & $2 / 25$ & $1 / 9$ & $0 / 46$ \\
Rocks Canyon & $(33.3 \%)$ & $(8.0 \%)$ & $(11.1 \%)$ & $(0)$ \\
Total & $38 / 100$ & $2 / 25$ & $2 / 11$ & $0 / 132$ \\
\multicolumn{5}{l}{} \\
\multicolumn{2}{l}{ a Number of rats seropositive/number of rats sampled (\%). } \\
\hline
\end{tabular}

(Figure 2). Peak MNAs were in August 1995, August to September 1996, July 1997, June and September 1998, and August to September 1999, indicating months of peak population density. Highest MNIs were also during August to November 1995 (Figure 2). ESPs peaked during November 1995 to May 1996 and generally declined thereafter until late summer 1999 (Figure 2).

Weights varied considerably from capture to capture, with increases being the greatest in younger woodrats, a few increasing $20 \mathrm{~g}$ to $50 \mathrm{~g}$ in a 3- to 4 -month period. A few adult woodrats lost weight, as much as $20 \mathrm{~g}$ within a 6 -week period. Most large weight losses occurred during late summer to the end of autumn or in mid-winter (data not shown). However, for most of the observation time, the woodrats' weight either increased $5 \mathrm{~g}$ to $15 \mathrm{~g}$ or remained stable.

Ten $(18.9 \%)$ of 53 juvenile female woodrats and none of 17 juvenile male woodrats had antibody to WWAV. Thirty-two (45.1\%) of 71 subadult female rats and $4(28.6 \%)$ of 14 subadult male rats were seropositive. Of adults, $34(55.7 \%)$ of

Table 1. Indirect fluorescent antibody ${ }^{a}$ (IFA) and enzyme-linked immunosorbent assays ${ }^{b}$ (ELISA) for antibody to Whitewater Arroyo virus (WWAV) in 306 blood samples from white-throated woodrats (Neotoma albigula) captured in southeastern Colorado, 1995-1999

\begin{tabular}{|c|c|c|c|c|c|c|c|c|c|c|c|}
\hline \multirow[b]{2}{*}{ IFA } & \multicolumn{11}{|c|}{ ELISA } \\
\hline & $<100$ & 100 & 200 & 400 & 800 & 1,600 & 3,200 & 6,400 & 12,800 & 25,600 & $>51,200$ \\
\hline 0 & 206 & 4 & 1 & 1 & 0 & 0 & 0 & 0 & 0 & 0 & 0 \\
\hline $1+$ & 1 & 0 & 0 & 0 & 0 & 0 & 0 & 0 & 0 & 0 & 0 \\
\hline $2+$ & 3 & 1 & 1 & 0 & 0 & 0 & 0 & 0 & 0 & 0 & 0 \\
\hline $3+$ & 3 & 0 & 1 & 1 & 4 & 1 & 0 & 0 & 1 & 0 & 0 \\
\hline $4+$ & 1 & 1 & 2 & 1 & 0 & 2 & 12 & 5 & 7 & 9 & 37 \\
\hline
\end{tabular}

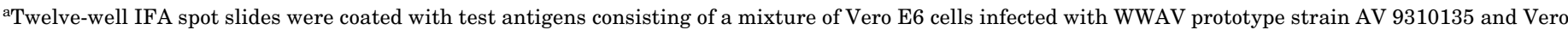

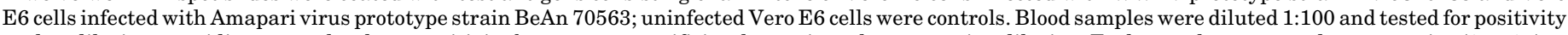

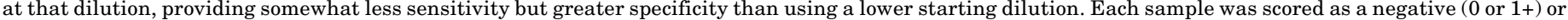
positive $(2+, 3+$, or $4+)$ serologic reaction. Antibody-positive samples were titrated in twofold dilutions to determine endpoints.

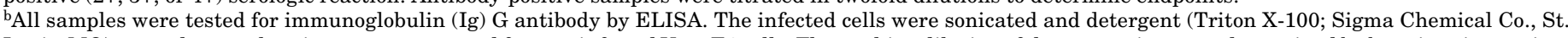

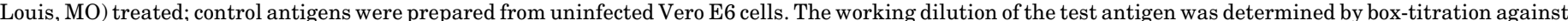

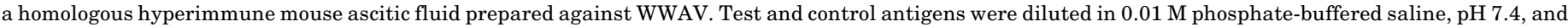

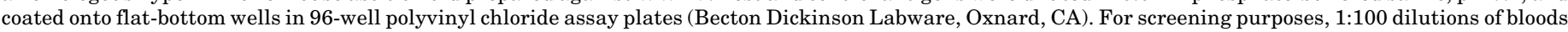

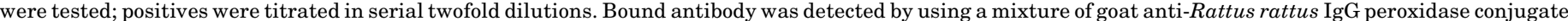

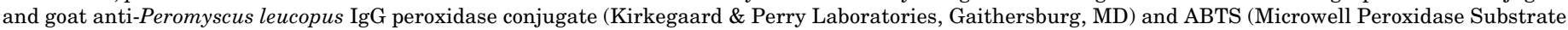

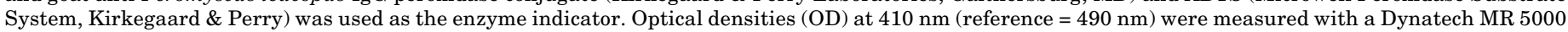

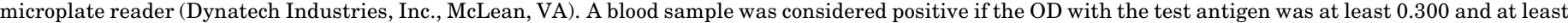
twice that of the same sample with the control antigen, providing the OD with the control antigen was $<0.150$. 


\section{Research}

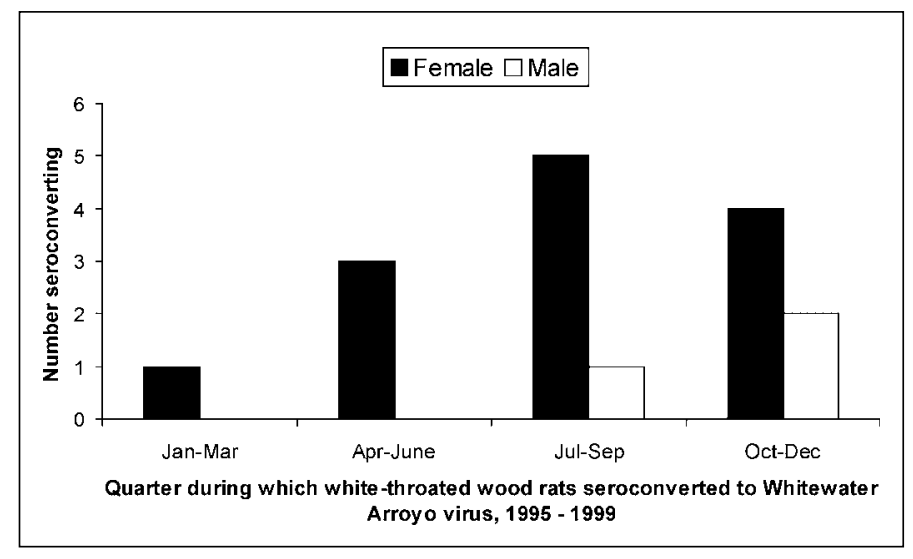

Figure 1. Quarter in which white-throated woodrats were first noted to have acquired antibody to Whitewater Arroyo virus in MRC and RRC sites, southeastern Colorado, 1995-1999.

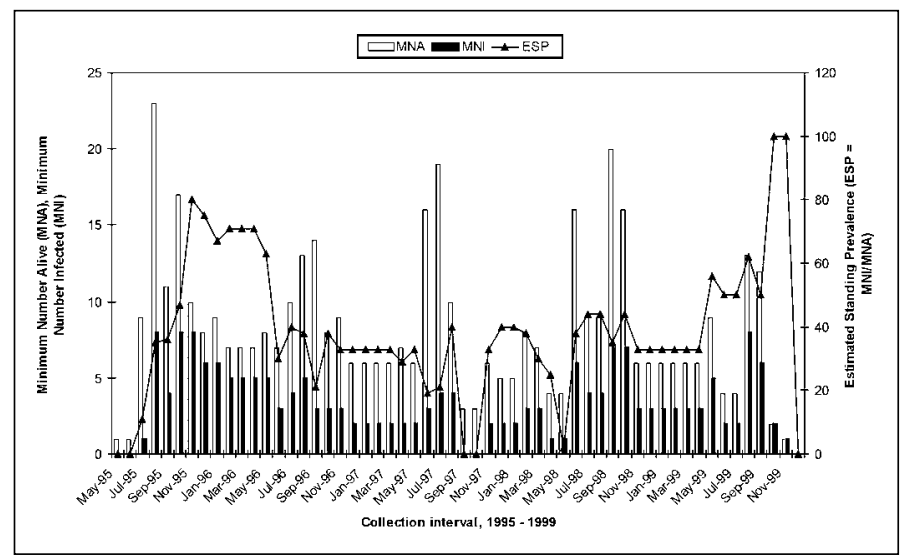

Figure 2. Minimum number alive (MNA), minimum number infected (MNI) with Whitewater Arroyo virus, and estimated standing prevalence (ESP=MNI/MNA), white-throated woodrats, southeastern Colorado, 1995-1999.

61 female rats and 18 (45\%) of 40 male rats were seropositive. In all, $14.3 \%$ of juveniles, $42.3 \%$ of subadults, and $51.5 \%$ of adult $N$. albigula had antibody to WWAV. None of eight gravid (as determined by increased weight and palpation) adult female rats and one that delivered a litter in the trap had antibody to WWAV.

Among 54 female and 33 male $N$. albigula captured only once, mean apparent longevity (number of months from first time captured and seropositive to last time captured) of 44 seropositive female rats was 7.8 months ( 2 to 19 months) and 10 seropositive male rats was 8.1 months (2 to 22 months). Mean apparent longevity (calculated from first to last time captured) of all seronegative female $N$. albigula was 8.1 months (2 to 12 months) and of all seronegative male $N$. albigula was 7.9 months (2 to 20 months). Mean longevities of uninfected and infected $N$. albigula did not differ significantly (Yates corrected chi-square 0.43, $\mathrm{p}=0.51$ ).

From 1995 to 1999 at the MRC site, N. albigula were captured in 52 of 145 traps. At the RRC site, rats were captured in 20 of 25 traps on the north line and 14 of 25 traps on the south line. Incidence was calculated by using the month in which antibody was first detected in recaptured $N$. albigula; data for both sites were pooled. In summary,
5 -year incidence rates from January to December were 0, 0 , $3.8,0,3.6,0,2.0,5.9,3.3,4.4,9.7$, and 0 . Overall incidences were 1.2 for December to July and 5.8 for August to November.

\section{Conclusion}

The characteristics and geographic distribution of WWAV have been described (2,3). Kosoy et al. (2) detected anti-arenaviral antibody in 1 of 7 white-throated woodrats trapped near Hesperus, La Plata County, southwestern Colorado. Arenaviruses are associated with persistent infections in the natural vertebrate host, even when the host is producing antibody (12). WWAV may also be maintained transseasonally in long-lived, persistently infected woodrats.

The prototype isolate of WWAV was from an N. albigula captured in McKinley County, New Mexico, approximately $500 \mathrm{~km}$ southwest of our study site. Kosoy et al. (2) did not detect anti-arenaviral antibody in three other $N$. albigula, five $N$. cinerea (bushy-tailed woodrats), two Mexican woodrats, or nine southern plains woodrats in Colorado, although they did detect antibody in Mexican woodrats collected in Arizona, New Mexico, and Utah. More than one arenavirus may be occurring in rats of the genus Neotoma and in deer mice and other rodents in southeastern Colorado. We have provided the first evidence that Mexican and southern plains woodrats in Colorado are infected with a WWAV-like arenavirus. Kosoy et al. did not detect anti-arenaviral antibody in eight hispid cotton rats from Colorado, and we did not detect antibody to WWAV in 132 of these rodents from PCMS. We detected antibody to WWAV in 1 of 2 whitethroated woodrats collected in Oklahoma (R. Nisbett et al., unpub. data). Thus, WWAV or a related virus is distributed widely in various Neotoma species in the southwestern United States, and serologic evidence strongly suggests that $N$. albigula is the primary rodent host of WWAV virus in southeastern Colorado.

Fulhorst (unpub. data) has shown that the arenavirus at PCMS differs genetically from the prototype strain, but it is clearly more similar to WWAV than to either Tamiami or Bear Canyon virus, the latter having been isolated from Peromyscus sp. rodents in California. Furthermore, the arenavirus associated with deer mice that had antibody to WWAV was also confirmed to be WWAV and may represent spillover transmission from infected rats.

White-throated woodrats have been described as solitary animals, with little social interaction among adults except for mating, which occurs mostly during late winter and spring until mid-June (7). The rate of new infections at PCMS is highest when the rat populations are largest (in late summer and fall), suggesting that mating may not be central to the transmission of this virus. Olsen (13) found that shelter-site selection by these rodents is based on quantity of ground-level vegetation and debris for cover. As neither the large area at the MRC site (traps 109 to 143) nor the central area of the RRC site include such flora or much debris, it is not surprising that we did not capture white-throated woodrats in these areas. Nevertheless, if white-throated woodrats gather in plots of preferred habitat, rat-to-rat contact is likely to increase, particularly when vegetative growth is reduced during the late fall-spring period. At high densities of populations of competing rat species, the probability of agonistic encounters increases. The Mexican woodrat, $N$. mexicana, may compete with $N$. albigula for den sites in 


\section{Research}

some areas (14), although the latter species appears dominant at the MRC and RRC sites. Such agonistic encounters could be a possible mechanism for interspecific WWAV transmission. Alternatively, another virus antigenically distinct from those used for the IFA (WWAV and Amapari virus) may be occurring in these species, and lack of sufficient cross-reactivity of antibody to this virus may explain the few positives detected.

The duration of this study allowed us to obtain data regarding the epizoology of WWAV. The high overall prevalence $(60 / 164=36.6 \%)$ of antibody to WWAV at PCMS and the fact that adults $(51.5 \%$ seropositive) were at higher risk for having antibody to WWAV indicate that infection with this virus is common and that older rats are more likely to be infected. Susceptibility of juvenile rats may be delayed as a result of protection by maternal antibody or because the behavior patterns of juvenile rats do not put them at risk for exposure to a contagious adult. The entrance of a cohort of young nonsusceptible rats may reduce the prevalence of antibody in the overall population.

Analyses of crude night-to-night movements showed no obvious difference between movement by white-throated woodrats with antibody to WWAV and those without, further suggesting that infection does not affect behavior. Increased rates of transmission are more likely during periods of higher population density because of increased overlapping home ranges and, therefore, increased rodent-to-rodent contact and potential for transmission.

Horizontal modes of transmission by rodent-to-rodent contact, particularly between mature rats, may be central to the maintenance of this virus in its rodent reservoir, but contact associated with mating is unlikely to be an important mechanism for transmission. The reason for this is unknown but could be related to sampling bias. The presence of longlived, virus-infected rodents appears important for transseasonal persistence of hantaviruses (15) and may be equally important for arenaviruses. Our observations may support such a hypothesis, given that white-throated woodrats at PCMS lived for as long as 22 months, some of them with antibody living longer than 1 year. Nonetheless, serologic data alone cannot determine if the woodrats sampled in this study were chronically infected and, if so, what type of infection resulted.

Arenaviruses characteristically produce chronic infections and can cause measurable physiologic effects in their reservoir hosts (12). Persistent infection after intranasal infection with Junin virus can increase deaths, reduce growth, and markedly reduce reproductive efficiency in its reservoir host, Calomys musculinus (16). A similar cyclical relationship has been observed between $C$. callosus and Machupo virus (12). In our study, none of 8 gravid adult N. albigula at PCMS (four each at MRC and RRC sites) had antibody to WWAV, whereas $34(60 \%)$ of 57 other adult female $N$. albigula that were not apparently gravid were seropositive. This may indicate that WWAV infection influences breeding in female $N$. albigula at these sites. Given that only $10(14.3 \%)$ of 70 juvenile $N$. albigula were seropositive and that WWAV-infected female rats may have reduced reproductive capacity, vertical transmission of WWAV is unlikely to cause infection rates as high as we observed. Although persistent infection of reservoir hosts is a hallmark of arenaviruses, not all viruses in this family establish chronic infections in all vertebrate hosts and such infections may be difficult to detect. Tamiami virus can be detected in kidneys and other organ systems of experimentally infected hispid cotton rats and virus can be recovered readily from urine $(17,18)$, but a chronic viremic carrier state does not develop. Determining whether the long-lived whitethroated woodrats with antibody at PCMS continue to shed WWAV will be key to our understanding of the persistence of this virus.

If the reproductive capacity of white-throated woodrats is compromised by infection with WWAV and the virus is more readily spread among rats when the population is large, we would expect subsequent generations to be smaller. This could be the result of decreased reproductive capacity in a significant portion of the mating female population ([65.9\% of the adult population was female] $\mathrm{x}[41.7 \%$ of adult females infected] $=27.5 \%$ of the total adult female population potentially, if temporarily, infertile), as adults are culled from the population by predators, disease, environmental hazards, and aging. The female preponderance in the $N$. albigula populations at MRC and RRC sites might indicate a sexbiased reduction in male rats resulting from intermittent food deprivation, as occurs with eastern woodrats (19).

Two types of observation bias are likely to have occurred in this study design. Most rats included in this longitudinal study were captured only once, and approximately $40 \%$ of first captures were in the first weight class. Rats captured only once, then, tend to be young. As rats observed for $>13$ weeks appear to have a greater relative risk for infection, and if age and season influence behavior, long-term survivors are likely to differ from those captured only once with respect to both exposures and presence of antibody. Consequently, the associations observed between the exposures and presence of antibody are likely to be biased towards a stronger association. Second, recording data subjectively, as in detecting pregnancy in female white-throated woodrats, may lead to misclassification bias. Some female rats thought not to be gravid may have been in the early stages of pregnancy or for other reasons may not have been correctly identified as gravid. Since palpation of fetuses was the main criteria for defining pregnancy, it is less likely that rats were incorrectly identified as gravid when they were not.

This study provided further information about the geographic distribution of arenaviruses associated with Neotoma sp. rodents. The data contribute to our understanding of the intraspecific transmission of this virus and the mechanisms underlying viral maintenance in natural populations of the white-throated woodrat, the probable rodent reservoir for WWAV in southeastern Colorado. WWAV was recently associated with fatal hemorrhagic infections in humans (20). Thus, knowledge of factors influencing WWAV transmission and changes in prevalence of infection of this virus in its natural host, the white-throated woodrat, may be useful in predicting periods of increased risk for human infections.

\section{Acknowledgments}

We thank Dan Sharps and Max Canestorp for identifying the plants and for insightful suggestions; Gary Belew, Dale Elliot, and Bob Hill for their logistical support; and Bill Sweeney, Ted Davis, and Gordon Smith for field assistance. 


\section{Research}

Rodents tested in these investigations were captured under a cooperative contract with the Centers for Disease Control and Prevention (U50/ccu809862-3). Dr. Fulhorst's research was supported in part by NIH grant AI-41435 ("Ecology of emerging arenaviruses in the southwestern United States").

Dr. Calisher is professor of microbiology, Arthropod-Borne and Infectious Diseases Laboratory, Department of Microbiology, Colorado State University. His areas of expertise and focuses of research are arboviruses, hantaviruses and other rodent-borne viruses, and viral evolution and taxonomy.

\section{References}

1. Peters CJ, Buchmeier M, Rollin PE, Ksiazek TG. Arenaviruses. In: Fields BN, Knipe DM, Howley PM, editors. Fields virology. 3rd ed. Philadelphia: Lippincott-Raven Publishers; 1996. p. 1521-44.

2. Kosoy MY, Elliott LH, Ksiazek TG, Fulhorst CF, Rollin PE, Childs $\mathrm{JE}$, et al. Prevalence of antibodies to arenaviruses in rodents from the southern and western United States: evidence for an arenavirus associated with the genus Neotoma. Am J Trop Med Hyg 1996;54:570-6.

3. Fulhorst CF, Bowen MD, Ksiazek TG, Rollin PE, Nichol ST, Kosoy MY, et al. Isolation and characterization of Whitewater Arroyo virus, a novel North American arenavirus. Virology 1996;224:114-20.

4. Calisher $\mathrm{CH}$, Tzianabos T, Lord RD, Coleman PH. Tamiami virus, a new member of the Tacaribe group. Am J Trop Med Hyg 1970;19:520-6.

5. Mills JN, Yates TL, Ksiazek TG, Peters CJ, Childs JE. Long-term studies of hantavirus reservoir populations in the southwestern United States: rationale, potential, and methods. Emerg Infect Dis 1999;5:95-101.

6. Calisher CH, Sweeney W, Mills JN, Beaty BJ. Natural history of hantaviruses in western Colorado, 1994-97. Emerg Infect Dis 1999;5:126-34.

7. Fitzgerald JP, Meaney CA, Armstrong DM. Mammals of Colorado. Niwot (CO): University Press of Colorado; 1994. 467 pages.
8. Feldmann HA, Sanchez A, Morzunov S, Spiropoulou CF, Rollin PE, Ksiazek TG, et al. Utilization of autopsy RNA for the synthesis of the nucleocapsid antigens of a newly recognized virus associated with hantaviral pulmonary syndrome. Virus Res 1993;30:351-67.

9. Dean AG, Dean JA, Burton AH, Dicker RC. Epi Info, Version 5: a word processing, database, and statistics program for epidemiology on microcomputers. Atlanta: Centers for Disease Control; 1990. p. 1-384.

10. Wulff $\mathrm{H}$, Lange JV, Webb PA. Interrelationships among arenaviruses measured by indirect immunofluorescence. Intervirology 1978;9:344-50.

11. Childs JE, Ksiazek TG, Spiropoulou CF, Krebs JW, Morzunov S, Maupin GO, et al. Serologic and genetic identification of Peromyscus maniculatus as the primary rodent reservoir for a new hantavirus in the southwestern United States. J Infect Dis 1994;169:1271-80.

12. Childs JE, Peters CJ. Ecology and epidemiology of arenaviruses and their hosts. In: Salvato MS, editor. The arenaviridae. New York: Plenum Press; 1993; p. 331-84.

13. Olsen RW. Shelter-site selection in the white-throated wood rat, Neotoma albigula. J Mammal 1973;54:594-610.

14. Howe R. Agonistic behavior of three sympatric species of wood rats (Neotoma mexicana, N. albigula, and N. stephensi). J Mammal 1978;59:780-6.

15. Mills JN, Ksiazek TG, Peters CJ, Childs JE. Long-term studies of hantavirus reservoir populations in the southwestern United States: a synthesis. Emerg Infect Dis 1999;5:135-42.

16. Vitullo AD, Hodara VL, Merani MS. Effect of persistent infection with Junin virus on growth and reproduction of its natural reservoir, Calomys musculinus. Am J Trop Med Hyg 1987;37:663-9.

17. Murphy FA, Winn WC Jr, Walker DH, Flemister MR, Whitfield SG. Early lymphoreticular viral tropism and antigen persistence: Tamiami virus infection in the cotton rat. Lab Invest 1976;34:125-40.

18. Jennings WL, Lewis AL, Sather GE, Pierce LV, Bond JO. Tamiami virus in the Tampa Bay area. Am J Trop Med Hyg 1970;19:527-36.

19. McClure PA. Sex-biased litter reduction in food-restricted wood rats (Neotoma floridana). Science 1981;211:1058-60.

20. Centers for Disease Control and Prevention. Fatal illnesses associated with a New World arenavirus-California, 1999-2000. MMWR Morb Mortal Wkly Rep 2000;49:709-11.

\section{Appendix}

Complete descriptions of this tract $(1,2)$ have characterized the area as follows: "Climate is classified as dry continental and elevation ranges from 1,300 to $1,700 \mathrm{~m}$. Topography consists of broad, moderately sloping uplands bordered by the Purgatoire River Canyon on the east, limestone hills on the west, and a basaltic hogback on the south. Vegetation is dominated by short grass prairie and piñon pine (Pinus edulis)-one-seeded juniper (Juniperus monosperma) woodland" (3). The piñon-juniper plant association is concentrated along the Purgatoire River Canyon and its side canyons, in the limestone hills, and on parts of the basaltic hogback.

Two trapping sites were established in January 1995, one at the mouth of Red Rocks Canyon (MRC) and one within Red Rocks Canyon (RRC). The MRC site was a 3.14-ha web, containing twelve 100-m transects radiating from a central point, resembling the spokes of a wheel; additional details have been published (4). The MRC site, located at N $37^{\circ} 32^{\prime} 48.8^{\prime \prime}$, W $103^{\circ} 49^{\prime} 34.3^{\prime \prime}, 1,675$ m elevation, is in an area characterized as recovering grassland, disturbed by previous human habitation. The center of the web is essentially flat, but the eastern and western sides are rocky, the eastern side comprising mostly rock outcroppings and the western side sloping steeply to a mesa, which is a piñon-juniper habitat. A natural spring forms a pond at the northwest side of the site; the water flows from this pond in a creek that runs southeast, bisecting the site, until it dissipates in the usually dry soil. From January 1995 until December 1999, there was water in the pond and for approximately $100 \mathrm{~m}$ downstream.
Only once, after an exceedingly heavy rain, did we observe water further down the creek bed. The soils at this site range from sandstone-derived slopes to sandy loam flat areas, with some marshy areas near the pond and its outlet. The slopes are 10\%-70\% bare ground; the western slope, being closer to the piñon-juniper mesa, is populated by sparse piñon pines and one-seeded junipers, and the eastern slope is mostly rocky outcroppings with sparse grasses and a few trees. Approximately $70 \%$ of the flora of the flatter areas is grasses, mostly Japanese brome (Bromus japonicus), blue grama (Bouteloua gracilis), and sideoats grama (B. curtipendula); 5\% shrubs, mostly Louisiana sagebrush (Artemesia ludoviciana), milkvetch (Astragalus crassicarpus), and other sages (Artemesia sp.); $20 \%$ forbs, mostly skunkbrush sumac (Rhus trilobata), broom snakeweed, (Gutierrezia sarothrae), and rabbitbrush (Chrysothamnus nauseosus); and 5\% cacti, mostly soapweed (Yucca glauca) and plains prickly pear (Opuntia polycantha var. polycantha).

Because the canyon at the RRC site is too narrow to install a web, we placed three parallel east-west lines of traps approximately $50 \mathrm{~m}$ apart, on the north side, in the middle, and on the south side of the canyon. Twenty-five traps were spaced $10 \mathrm{~m}$ apart on each line. The center of the middle line was located at N $37^{\circ} 32^{\prime} 19.3^{\prime \prime}, \mathrm{W} 103^{\circ}$ $49^{\prime} 12.5 ", 1,500 \mathrm{~m}$ elevation.

The RRC site is a vacant former homestead that still contains residences and outbuildings, with an east-west gravel road traversing it. An arroyo, dry most of the time, originates west of the site and bisects the site roughly west to east. The north line of traps 


\section{Research}

was placed on a south-facing slope, which has sandstone-derived soil. This area mostly comprises rocky outcroppings, some piñon pine and one-seeded junipers, very sparse grasses (mostly Japanese brome and blue grama), forbs (mostly skunkbrush sumac and rabbitbrush), shrubs (mostly sages and skunkbrush sumac), and cacti (essentially all tree cholla, O. imbricata); $20 \%$ of the ground was bare during most seasons and most years. The south line (at the base of a north-facing slope), also on sandstone-derived soil, was similar to the north line, with somewhat more rocks and shrubs (mostly skunkbrush sumac). The middle line was placed in an area that had been severely disturbed from decades of vegetation and water utilization and hoof compaction but is now recovering. It is primarily deep sandy loam bottomland, with alluvial soils. Grasses comprised $10 \%$ of the flora, mostly Japanese brome); forbs 55\%, mostly pinnate tansymustard (Descurainia pinnata); shrubs 15\%, mostly rabbitbrush; and cacti 5\%, mostly plains prickly pear); $15 \%$ of the middle line area was bare ground.

\section{References}

1. Shaw RB, Anderson SL, Schultz KA, Diersing VE. Plant communities, ecological checklist, and species list for the U.S. Army Piñon Canyon Maneuver Site, Colorado. Fort Collins (CO): Colorado State University, Science Series No. 37; 1989. p. 71.

2. U.S. Department of the Army. Draft environmental impact statement for training land acquisition. Fort Carson, Colorado, 1980.

3. Costello DF. Vegetation zones in Colorado. In: Harrington HD, editor. Manual of the plants of Colorado. Chicago: Swallow Press, Inc.; 1954. p. iii-x.

4. Mills JN, Yates TL, Ksiazek TG, Peters CJ, Childs JE. Long-term studies of hantavirus reservoir populations in the southwestern United States: rationale, potential, and methods. Emerg Infect Dis 1999;5:95-101. 